\author{
Krzysztof CHŁAPOWSKI \\ https://orcid.org/0000-0003-1539-4519 \\ The Tadeusz Manteuffel Institute of History \\ of the Polish Academy of Sciences
}

\title{
The summary of Metrica Regni Poloniae no. 139 dated to 1595
}

\begin{abstract}
Zarys treści: Artykuł referuje prace prowadzone nad edycją Metryki Koronnej w formie regestów w języku polskim, zgodnie z zasadami ustalonymi w 1999 r. Księgi tej serii źródłowej zawierają wpisy dokumentów wystawionych w imieniu króla dotyczących wszelkich spraw, w których decyzja należała do króla. Zostało tu oblatowanych, inserowanych, streszczonych lub tylko wspomnianych 35 dokumentów wystawionych przez poprzedników Zygmunta III na tronie. Księga nr 139 to czwarta z sześciu ksiąg kancelarii mniejszej Jana Tarnowskiego, obejmująca 430 wpisów, niemal wyłącznie po łacinie. Ich największa liczba przypada na marzec, czyli okres obradowania sejmu. Edycja jest opatrzona przypisami i indeksem.
\end{abstract}

\begin{abstract}
The article presents works on the edition of the Crown Metrica in the form of abstracts in Polish, in accordance with the editorial rules and requirements established in 1999. The books of this source series contain entries of documents issued on behalf of the king regarding all matters in which the decision belonged to the king. Thirty five documents issued by the predecessors of King Sigismund III Vasa have been entered here, inserted, summarized or only mentioned. Book no. 139 is the fourth of six books of the lesser chancellery of Jan Tarnowski, covering 430 entries, almost exclusively in Latin. Their largest number falls to March, which is the period of the Sejm session. The edition has been supplemented with footnotes and an index.
\end{abstract}

Słowa kluczowe: Polska, nowożytność, Metryka Koronna, edycje źródłowe

Keywords: Poland, early modern era, Crown Metrica, source editions

The works on the summary of Metrica Regni Poloniae (Pl. Metryka Koronna, Eng. Crown Metrica) comprising the registers of the books in the form of the entries summarising the documents entered therein have been under way for nearly twenty years ${ }^{1}$. Their purpose is to grant access to them to a wider range of users, especially those who had only rudimentary or no knowledge of Latin. Nearly twenty years ago, the summary of the Crown Metrica in Latin, which had been initiated in the early twentieth century $^{2}$, was abandoned. The Crown Metrica is the fruit of works of royal chanceries (of higher and lower level in the hierarchy) that served an auxiliary role in the implementation of the royal foreign and internal policies and at the same time were the most important 'public trust' office, warranted by the king's authority. That is why the Crown Metrica is a basic source of information on the history

\footnotetext{
${ }^{1}$ More about it see: K. Chłapowski, Sumaryzacja Metryki Koronnej po polsku, “Arcana”, 92/93 (2/3), 2010, p. 41-49.

${ }^{2}$ Matricularum Regni Poloniae Summaria, vol. 1-5/1, ed. T. Wierzbowski, Warszawa 1905-1919, vol. 5/2, eds. J. Płocha, A. Rybarski, I. Sułkowska, Warszawa 1961, vol. 6, ed. M. Woźniakowa, Warszawa 1999.
} 
of medieval and early modern Poland. The books contain the registers of the documents issued in the name of the king in the cases where he played a decisive role $^{3}$, ranging from regional to the state-level ones. The decisions entered into the books concerned the operation of the state as well as local councils. Thus, it is of no surprise that their publication was deemed a priority due to both the importance of the office where they were prepared and the abundance of information they carried ${ }^{4}$.

The summary in Latin covered the Crown Metrica from the time this type of documents began to be issued in the chanceries of different level until the year 1574. The decision to summary the Metica in Polish was taken during the seminar of archivists and historians in the Central Archives of Historical Records (Pl. Archiwum Główne Akt Dawnych) in Warsaw, in November 1999. It was concluded that it would make the records available to a wider public and accelerate the editorial works. Making summaries of documents in Polish had long been in practice in Polish historical sciences and had been implemented in a variety of collections of documents in the archives of the most important Polish scientific libraries as well as in case of the court books 5 . In order to accelerate the printing of the Crown Metrica's summary, only one book of registers was to be included in one volume, contrary to the previous practice of publishing all the books prepared under one king. Some basic rules of the edition and preparation of the Metrica were established.

It was also decided that the works on the books dating back to the times of Stephen Báthory, Sigismund III and, in the longer perspective, Władysław IV, would all be conducted separately. Wojciech Krawczuk, the author and editor of the works on the Crown Metrica and their history, was appointed the editor of the series ${ }^{6}$. Later on, the position of the editor was given to Krzysztof Chłapowski, the author of works on the period of King Sigismund III and editor of historical text sources as a person experienced in editing of such summaries. The works were to be financed with grants acquired later.

First, the summary of the Crown Metrica from the times of King Sigismund III was initiated, resulting in publication of seven volumes containing the entries of books nos. 133-139 from the years between 1587 and 1595 (4017 abstracts) edited thus far. The volumes are numbered from two to eight (II-VIII) ${ }^{7}$.

\footnotetext{
${ }^{3}$ K. Chłapowski, Sumaryzacja, p. 41-42.

${ }^{4}$ It has to be concluded that, according to a widespread opinion among historians, there is no collection of documents more important for the late Middle Ages and Early Modern Era than the Crown Metrica.

${ }_{5}$ Akta grodzkie i ziemskie z czasów Rzeczypospolitej Polskiej z archiwum tak zwanego bernardyńskiego we Lwowie w skutek fundacyi śp. Alexandra hr. Stadnickiego, vol. 10, eds. O. Pietruski, K. Liske, Lwów 1884; Katalog dokumentów Biblioteki Zakładu Narodowego im. Ossolińskich, part 1: Dokumenty z lat 1507-1700, ed. A. Fastnacht, Wrocław 1953, part 2: Dokumenty z lat 1701-1939. Dodatek dokumenty z lat 1282-1909, ed. A. Fastnacht, Kraków 1969; Katalog dokumentów pergaminowych Biblioteki Polskiej Akademii Nauk, part 1: Dokumenty z lat 1131-1571, ed. K. Dziwik, Wrocław-Warszawa-Kraków 1966, part 2: Dokumenty z lat 1573-1787, ed. K. Dziwik, Wrocław-Warszawa-Kraków 1968, part 3: Dokumenty z lat 1403-1797, ed. K. Dziwik, Wrocław-Warszawa-Kraków 1970; Katalog dokumentów pergaminowych Biblioteki Czartoryskich w Krakowie, part 1: Dokumenty z lat 1148-1506, eds. W. Szelińska, J. Tomaszewicz, Kraków 1975, part 2: Dokumenty z lat 1506-1828, ed. J. Tomaszewicz, Kraków 1991.

${ }^{6}$ W. Krawczuk, Pisarze kancelarii koronnych Zygmunta III Wazy, St. Hist., 36, 1993, p. 149-164; id., Metryka Koronna za Zygmunta III Wazy. Początki Archiwum Koronnego Warszawskiego w świetle spisów z 1620 i 1627 roku, Kraków 1995; id., Kancelaria Koronna a Sejm Walny. Instructuarium, Warszawa 1995; id., Metrykanci Koronni. Rozwój registratury centralnej od XVI do XVIII wieku, Kraków 2002.

${ }^{7}$ Księga wpisów kanclerza Jana Zamoyskiego MK 133 z Archiwum Głównego Akt Dawnych w Warszawie: lata 1587-1595, ed. W. Krawczuk, prep. A. Kot, W. Krawczuk, M. Kulecki, A. Sokół, G. Spyrka, Kraków 2001 (series: Sumariusz Metryki Koronnej. Seria Nowa, vol. 2); Księga wpisów podkanclerzego Wojciecha Baranowskiego MK 134 z Archiwum Głównego Akt Dawnych w Warszawie 1587 - V 1588, ed. W. Krawczuk, prep. M. Kulecki, A. Markiewicz, K.J. Stachelski, A. Sokół, Kraków 2004 (series: Sumariusz Metryki Koronnej. Seria Nowa, vol. 3); Księga wpisów podkanclerzego koronnego Wojciecha Baranowskiego z okresu marzec 1588 - grudzień 1590 MK 135 z Archiwum Głównego Akt Dawnych w Warszawie, prep. W. Krawczuk, M. Kulecki, Kraków 2010 (series: Sumariusz Metryki Koronnej. Seria Nowa, vol. 4); Księga wpisów podkanclerzego Jana Tarnowskiego MK 136 z Archiwum Głównego Akt Dawnych w Warszawie 1591, prep. K. Chłapowski, Warszawa 2009 (series: Sumariusz Metryki Koronnej. Seria Nowa, vol. 5); Księga wpisów podkanclerzego Jana Tarnowskiego MK 137 z Archiwum Głównego Akt Dawnych w Warszawie 1592, prep. K. Chłapowski, Warszawa 2012 (series: Sumariusz Metryki Koronnej. Seria Nowa, vol. 6); Księga wpisów podkanclerzego Jana Tarnowskiego MK 138 z Archiwum Głównego w Warszawie 1593-1594, prep. K. Chłapowski, Warszawa 2014 (series: Sumariusz Metryki Koronnej. Seria Nowa, vol. 7).
} 
The volume two and three were prepared by a larger scientific team; volume four - by Wojciech Krawczuk; and volumes from five to eight - by Krzysztof Chłapowski. It is worth noting that the first volume of the series was Wojciech Krawczuk's summary of the Crown Metrica by Chancellor of Poland Tomasz Zamoyski from 1628-1635, currently in the archives of Riksarchivet in Stockholm8.

The work on the summary of the Crown Metrica from the times of King Władysław IV in Polish language has started recently. It is conducted by two teams under Wojciech Krawczuk and Jan Dąbrowski. The first effects of their works have been published online. The team working on the Stephen Báthory's Crown Metrica, despite several attempts, have not been granted any funding, which is quite surprising if not preposterous. However, the scientific value of the summary of the Crown Metrica, its relatively low cost due to the lack of expensive archive queries, possibility to use contents of the books (Latin text) in the form of scans that had been prepared by the Polish Heraldry Society (Pl. Polskie Towarzystwo Heraldyczne) and Central Archives of Historical Records, combined with great determination of the researchers seem to contribute greatly to the summary project's future success.

The volume eight of the New Crown Metrica's Series includes the documents registered in the Crown Metrica no. 139 by Chancellor Jan Tarnowski throughout the entire year 1595 (430 documents) ${ }^{9}$. The book no. 139 is the fourth out of six prepared in the office of Chancellor Jan Tarnowski. The chancellery under Jan Zamoyski, which was higher in the hierarchy, operated only during the Sejm sessions and shortly afterwards, as Chancellor Jan Zamoyski was in opposition to King Sigismund III ${ }^{10}$. To Zamoyski's death, the Tarnowski's chancellery had been, in fact, the only one in operation.

The book of entries to the Crown Metrica no. 139 is well preserved and numbers 404 pages. On the cover and the title page, there is a title, and at the back there is an authentication and the signature of Jan Tarnowski's deputy chancellor ${ }^{11}$. The researcher attempting to summarise the Crown Metrica needs to bear in mind that abstracts are acknowledged form of source editions ${ }^{12}$ which means that the resulting publication will contain a set of registers treated as source publications despite not strictly being one. It is not an edition of the original source documents but a register of their summaries. The researcher is obliged to summarise the entries and to represent the content with no misinterpretations and falsifications (dispositio) as well as to apply the rules of the editing of historical sources. Thus, the summary is one of the forms of source presentation and editorial preparation. The user, however, needs to remember that the abstracts cannot replace the original documents.

In the Metrica no. 139 the entries are, similarly to the other books, ordered chronologically with some minor deviations from the rule probably due to some backlogs in the work of the chancellery, which had to be accounted for. What is characteristic for this book is that out of its 430 documents, 114 of them, accounting for 26.5 per cent, are registers of private documents, which makes it significantly more than in the previous books ${ }^{13}$. That is because Mikołaj Jazłowiecki, who occupied the position of Starosta of Śniatyń, Sokal and Czerwonogród district, owing to his terminal illness entered into the books as many as 33 donations for private persons and Church institutions, and appointed the executors of his will. He believed that registering his document in the Crown Metrica served as better authentication than subjecting the documents to the appropriate magistrate court.

\footnotetext{
${ }^{8}$ Księga wpisów kancelarii koronnej podkanclerzego Tomasza Zamoyskiego z lat 1628-1635 ze zbiorów sztokholmskiego Riksarkivet sygnatura Skokloster E[nskilda] 8636, ed. W. Krawczuk, Kraków 1999 (series: Sumariusz Metryki Koronnej. Seria nowa, vol. 1).

9 The number of the entries in the previously published volumes ranges from 344 to 1086 .

${ }^{10}$ In 1595, the number of entries to the Crown Metrica by Jan Zamoyski accounted for only 28; they concerned his political supporters and clients. In the following years his chancellery ceased to operate.

${ }_{11}$ Inwentarz Metryki Koronnej. Księgi wpisów i dekretów polskiej kancelarii królewskiej z lat 1447-1795, eds. I. Sułkowska-Kurasiowa, and M. Woźniakowa, Warszawa 1975, p. 64-65.

12 Instrukcja wydawnicza do źródel historycznych od XVI do połowy XIX wieku, ed. K. Lepszy, Wrocław 1953, p. 1, 9.

${ }_{13}$ According to W. Krawczyk, the percentage for Sigismund III was 20 per cent on average, varying from 9 per cent to 37 per cent, depending on the volume.
} 
The Crown Metrica contains such documents as: debt papers, letters of attorney, documents confirming debt collection, cession and settlement of debt, dowry, children's guardian or custodian appointment, also bequest for Church institutions, selling of goods, and division of property. The royal documents mostly referred to the royal property (ca 50 per cent), but also comprised the appointments to offices and positions, also ecclesiastical ones, e.g. abbeys and bishoprics, foundation charters for towns and their confirmation, etc. In time, half of the Metrica contained private documents, and the books became quasi-central state-governed court books, though it was not until the second half of the seventeenth century.

The intensity of work of the chancellery in the first years of King Sigismund III's rule, measured in number and dynamic of entries to the Crown Metrica, can be illustrated as follows:

Table 1. The dynamics of entries to the Crown Metrics in years 1588-1596

\begin{tabular}{|l|r|r|r|r|r|r|r|r|r|}
\hline \multicolumn{1}{|c|}{ Month } & $\mathbf{1 5 8 8}$ & $\mathbf{1 5 8 9}$ & $\mathbf{1 5 9 0}$ & $\mathbf{1 5 9 1}$ & $\mathbf{1 5 9 2}$ & $\mathbf{1 5 9 3}$ & $\mathbf{1 5 9 4}$ & $\mathbf{1 5 9 5}$ & $\mathbf{1 5 9 6}$ \\
\hline January & 159 & 40 & 17 & 112 & 29 & 31 & 5 & 18 & 50 \\
\hline February & 91 & 24 & 8 & 18 & 34 & 20 & 2 & 46 & 20 \\
\hline March & 91 & 64 & 32 & 40 & 26 & 40 & 1 & 110 & 31 \\
\hline April & 61 & 205 & 142 & 27 & 39 & 21 & 4 & 25 & 42 \\
\hline May & 60 & 89 & 46 & 31 & 28 & 64 & 6 & 30 & 67 \\
\hline June & 103 & 61 & 15 & 50 & 89 & 168 & 3 & 15 & 12 \\
\hline July & 55 & 14 & 17 & 49 & 47 & 50 & 8 & 34 & 25 \\
\hline August & 67 & 22 & 21 & 36 & 22 & 56 & 14 & 61 & 21 \\
\hline September & 61 & 19 & 18 & 9 & 44 & 31 & 16 & 25 & 8 \\
\hline October & 22 & 19 & 13 & 26 & 136 & 1 & 46 & 20 & 11 \\
\hline November & 50 & 12 & 17 & 26 & 25 & 1 & 36 & 19 & 7 \\
\hline December & 20 & 13 & 19 & 30 & 30 & 8 & 36 & 27 & 22 \\
\hline Total & $\mathbf{8 2 5}$ & $\mathbf{5 8 2}$ & $\mathbf{3 6 5}$ & $\mathbf{4 5 4}$ & $\mathbf{5 0 6}$ & $\mathbf{4 9 1}$ & $\mathbf{1 7 7}$ & $\mathbf{4 3 0}$ & $\mathbf{3 1 6}$ \\
\hline
\end{tabular}

Source: see fn. 7 .

There was a greater number of entries at the end and directly after the Sejm sessions, as it was when the MPs had an opportunity to deal with any official business in the Crown's chancellery. In the period covered by the table above, the Sejm sessions took place on: 10 December 1587 - 30 January 1588; 6 March - 23 April 1589; 8 March - 21 April 1590; 2 December 1590 - 15 January 1591; 7 September - 19 October 1592; 4 May - 16 June 1593; 6 February - 21 March 1595; and 26 March - 13 May 1596, while in 1594 the sessions did not take place due to the absence of the king.

In 1588, King Sigismund III ascended to the throne and it was then he dealt with all the issues that had arisen in the interregnum period, created his group of supporters by acts of clemency, and awarding the participants of the Battle of Byczyna with lands and offices, which resulted in a greater number of entries in the Crown Metrics. On 23 May 1588, King Stephen Bátory's funeral took place, while Sigismund III married Anne of Austria on 31 May 1592. A great number of people came to the events, which increased the number of entries. In August 1595 and January 1596, the high number of entries resulted from 33 registers by Mikołaj Jazłowiecki, and from 16 entries by the Krasicki family.

On the other hand, during the harvest, the number of entries decreased. Similarly, during King Sigismund III's venture to Sweden between September 1593 and August 1594, and to Livonia in the second half of 1589, when he met King John III of Sweden in Reval (Tallinn), the chancellery nearly ceased to operate, which resulted in smaller number of registers. The decrease of interest in the services of the chancellery in 1591 can be seen as caused by the roaming plague, which intensified in September, making the king and his court leave Krakow. 
Usually, the entries into the Crown Metrica were made in Latin, and only 2.8 per cent of those found in the book no. 139 were in put in their entirety or part in Polish (except for promulgations and specifications of the authors, which were in Latin). It is less than in the previous books. In the second half of the sixteenth century, the Polish language was gradually gaining the role of an official language. Neither it contains documents in German, which could be found in previous books. None of the entries in Polish are of private character. One concerns the international affairs (a copy of a testament of the Moldavia's overlord who instructed his successor on international affairs ${ }^{14}$ ), two pertain to the regional-scope public affairs (a copy of a Bill issued by the Łęczyca Voivodeship's Council on taxes and calling the voivodeship sejmik wrongly $)^{15}$, one is a confirmation of issuing a book registering the documents of Crown Treasury Archives from the years 1550-1551 to Jan Skrzetuski by Marcin Kromer ${ }^{16}$, three of them are the documents issued by the royal officials ${ }^{17}$, one is a summary of Town Court files with a copy of the audit of the Cieżkowice holding from the king from the year $1564^{18}$.

The Crown Metrica no. 139 also contains the copies, insertions and summaries of the documents issued by King Sigismund III's predecessors. They account for 35 documents (while, in other books, their number was even bigger). The oldest dates to year 1253 and was issued by Princes Przemysław and Bolesław of Greater Poland's, while establishing Śrem Voivodeship ${ }^{19}$. Two documents dated to 29 November 1348 and 1 February 1355 were issued by King Casimir III the Great ${ }^{20}$. It is of no surprise, however, that the documents issued by Sigismund Augustus and Stephen Báthory were by far the most numerous (17 in total).

The summary of the Crown Metrica no. 139 is also supplemented with footnotes explaining more difficult or only briefly mentioned terms crucial for understanding the document, or containing the names of persons and location of the settlements in a voivodeship or a district, and describing the persons and the family relations between them to render the document clear and easy to understand. The date and place of publication or registration of the document is also mentioned, although regarded as not necessary by some researchers. The scope of the content within the footnote depends on the person summarising the book. However, as far as my work is concerned, all the information above were included. A detailed list of witnesses is also considered additional information. Yet, from the volume five onwards, it has become a standard practice in the summaries as it increases its information value at relatively low cost of space owing to the fact that there is a relatively small number of documents with a full witness list. It is stated whether and where the document had been previously published in extenso or registered, which is also not seen as necessary by some of researchers. I, however, assumed that it is justified, and I have prepared such an inventory, similarly to the other volumes I had edited previously.

The summary of The Crown Metrica no. 139 is part of a greater scientific project of great importance, which is also time-consuming and requiring the researcher to be highly qualified, though surprisingly inexpensive, as it was mentioned above. The fact that many authors and source editors frequently refer to it in their works proves it has settled in the scientific landscape.

Author: Krzysztof Chłapowski is a Professor Emeritus in The Tadeusz Manteuffel Institute of History, Polish Academy of Sciences, associated with the Department of the Historical Atlas. His research interests focus on the early modern age, historical geography and source editing.

Instytut Historii im. Tadeusza Manteuffla Polskiej Akademii Nauk

Rynek Starego Miasta 29/31

00-272 Warszawa

e-mail: kkchlapowski@gmail.com

\footnotetext{
${ }^{14}$ Abstract no. 188.

${ }^{15}$ Abstract no. 198.

${ }_{16}$ Abstract no. 351.

17 Abstracts nos. 5, 161, 296.

18 Abstract no. 430.

${ }^{19}$ Abstract no. 301.

${ }^{20}$ Abstracts nos. 88 and 429.
} 


\section{Bibliography}

\section{Primary sources}

Akta grodzkie i ziemskie z czasów Rzeczypospolitej Polskiej: z archiwum tak zwanego bernardyńskiego we Lwowie w skutek fundacyi śp. Alexandra hr. Stadnickiego, vol. 10, eds. O. Pietruski, K. Liske, Lwów 1884

Inwentarz Metryki Koronnej. Księgi wpisów i dekretów polskiej kancelarii królewskiej z lat 1447-1795, eds. I. Sułkowska-Kurasiowa, M. Woźniakowa, Warszawa 1975

Katalog dokumentów Biblioteki Zakładu Narodowego im. Ossolińskich, part 1: Dokumenty z lat 1507-1700, ed. A. Fastnacht, Wrocław 1953, part 2: Dokumenty z lat 1701-1939, and Dodatek. Dokumenty z lat 1282-1909, ed. A. Fastnacht, Kraków 1969

Katalog dokumentów pergaminowych Biblioteki Czartoryskich w Krakowie, part 1: Dokumenty z lat 1148-1506, eds. W. Szelińska, J. Tomaszewicz, Kraków 1975, part 2: Dokumenty z lat 1506-1828, ed. J. Tomaszewicz, Kraków 1991

Katalog dokumentów pergaminowych Biblioteki Polskiej Akademii Nauk w Krakowie, part 1: Dokumenty z lat 1131-1571, ed. K. Dziwik, Wrocław-Warszawa-Kraków 1966, part 2: Dokumenty z lat 1573-1787, ed. K. Dziwik, Wrocław-Warszawa-Kraków 1968, part 3: Dokumenty z lat 1403-1797, ed. K. Dziwik, Wrocław-Warszawa-Kraków 1970

Księga wpisów kancelarii koronnej podkanclerzego Tomasza Zamoyskiego z lat 1628-1635 ze zbiorów sztokholmskiego Riksarkivet sygnatura Skokloster E[nskilda] 8636, ed. W. Krawczuk, Kraków 1999 (series: Sumariusz Metryki Koronnej. Seria nowa, vol. 1)

Księga wpisów kanclerza Jana Zamoyskiego MK 133 z Archiwum Głównego Akt Dawnych w Warszawie: lata 1587-1595, ed. W. Krawczuk, prep. A. Kot, W. Krawczuk, M. Kulecki, A. Sokół, G. Spyrka, Kraków 2001 (series: Sumariusz Metryki Koronnej. Seria Nowa, vol. 2)

Księga wpisów podkanclerzego Wojciecha Baranowskiego MK 134 z Archiwum Głównego Akt Dawnych w Warszawie 1587 - V 1588, ed. W. Krawczuk, prep. M. Kulecki, A. Markiewicz, K.J. Stachelski, A. Sokół, Kraków 2004 (series: Sumariusz Metryki Koronnej. Seria Nowa, vol. 3)

Księga wpisów podkanclerzego koronnego Wojciecha Baranowskiego z okresu marzec 1588 - grudzień 1590 MK 135 z Archiwum Głównego Akt Dawnych w Warszawie, prep. W. Krawczuk, M. Kulecki, Kraków 2010 (series: Sumariusz Metryki Koronnej. Seria Nowa, vol. 4)

Księga wpisów podkanclerzego Jana Tarnowskiego MK 136 z Archiwum Glównego Akt Dawnych w Warszawie 1591, prep. K. Chłapowski, Warszawa 2009 (series: Sumariusz Metryki Koronnej. Seria Nowa, vol. 5)

Księga wpisów podkanclerzego Jana Tarnowskiego MK 137 z Archiwum Gtównego Akt Dawnych w Warszawie 1592, prep. K. Chłapowski, Warszawa 2012 (series: Sumariusz Metryki Koronnej. Seria Nowa, vol. 6)

Księga wpisów podkanclerzego Jana Tarnowskiego MK 138 z Archiwum Głównego w Warszawie 1593-1594, prep. K. Chłapowski, Warszawa 2014 (series: Sumariusz Metryki Koronnej. Seria Nowa, vol. 7)

Matricularum Regni Poloniae Summaria, vol. 1-5/1, ed. T. Wierzbowski, Warszawa 1905-1919; vol. 5/2, eds. J. Płocha, A. Rybarski, I. Sułkowska, Warszawa 1961; vol. 6, ed. M. Woźniakowa, Warszawa 1999

\section{Secondary sources}

Chłapowski K., Sumaryzacja Metryki Koronnej po polsku, "Arcana", 92/93 (2/3), 2010, p. 41-49

Instrukcja wydawnicza do źródet historycznych od XVI do połowy XIX wieku, ed. K. Lepszy, Wrocław 1953

Krawczuk W., Kancelaria Koronna a Sejm Walny. Instructuarium, Warszawa 1995

Krawczuk W., Metryka Koronna za Zygmunta III Wazy. Początki Archiwum Koronnego Warszawskiego w świetle spisów z 1620 i 1627 roku, Kraków 1995

Krawczuk W., Metrykanci koronni. Rozwój registratury centralnej od XVI do XVIII wieku, Kraków 2002

Krawczuk W., Pisarze kancelarii koronnych Zygmunta III Wazy, St. Hist., 36, 1993, p. 149-164 